\title{
Haze Attitudes and the Willingness to Pay for Haze Improvement: Evidence from Four Cities in Shandong Province, China
}

\author{
Fan Yang ${ }^{1}$, Ling Ding ${ }^{2}$, Cai Liu ${ }^{3}$, Lizheng $X u^{1}$, Stephen Nicholas $4,5,6, * \mathbb{C}$ and Jian Wang ${ }^{1, * \mathbb{C}}$
}

1 Center for Health Economics Experiment and Public Policy, School of Public Health, Shandong University, No. 44 Wenhuaxi Road, Lixia, District, Jinan 250012, China; 15153132375@163.com (F.Y.); sddxxlz@163.com (L.X.)

2 Tianjin Hongqiao District Health and Family Planning Commission, 202 Qinjian Road, Hongqiao 300131, China; wydl1222@163.com

3 School of Management, Tianjin University of Traditional Chinese Medicine, Tianjin 300193, China; keidy0707@163.com

4 School of Economics and School of Management, Tianjin Normal University, West Bin Shui Avenue, Tianjin 300074, China

5 TOP Education Institute, 1 Central Avenue Australian Technology Park, Eveleigh Sydney, NSW 2015, Australia

6 Newcastle Business School, University of Newcastle, University Drive, Newcastle, NSW 2308, Australia

* Corresponding author: stephen.nicholas@newcastle.edu.au (S.N.); wangjiannan@sdu.edu.cn (J.W.); Tel.: +44-(0)-7930942097 (S.N.); +86-13864157135 (J.W.)

Received: 15 August 2018; Accepted: 15 October 2018; Published: 19 October 2018

\begin{abstract}
Background: Given the health and welfare impacts of haze, haze reduction governance challenges Chinese policy-makers. Surprisingly, there have been no studies of the differences in the public's willingness to pay (WTP) for haze governance within a province. Yet haze reduction policies are implemented at the provincial level. Based on the contingent valuation method, data on WTP for haze governance across four industrial cities in Shandong province were collected using a questionnaire survey. Method: A combination of stratified sampling and non-probability sampling methods were used, yielding a valid sample of 1006 respondents. The Heckman sample selection model was used to analyze factors determining WTP and WTP amount. Results: $53 \%$ of respondents were unwilling to pay for haze reduction, while less than $1 \%$ of these respondents were satisfied with Shandong's air quality. About half (47\%) of the respondents were willing to pay, on average, US\$14.14 per household per year for haze governance. We found that there were significant inter-city differences in the WTP and WTP amounts: those with a higher income, education, haze knowledge, and haze concern were WTP; age, marital status, and subjective indicators displayed a negative relationship with WTP amount. About two thirds of the non-payers, and those with poor environmental knowledge, argued that air quality improvement was mainly the responsibility of governments $(39.3 \%)$ and polluters $(25.6 \%)$, instead of ordinary citizens. Further, $27 \%$ of non-payers said that their income was too low to contribute to a pollution tax and $6.3 \%$ claimed that they did not believe the funds would be used effectively for environmental conservation. Conclusions: City-specific differences in WTP may caution against "one size fits all" policies. The study indicates that the government may need to target policies to specific cities and the characteristics of residents in those cities by age, education, and income groups and residents' subjective evaluation of the government and the haze problem and those responsible for pollution.
\end{abstract}

Keywords: contingent valuation method; willingness to pay; haze governance; Shandong province 


\section{Introduction}

China's rapid industrialization and urbanization have given rise to unprecedented environmental challenges, including haze and water pollution, soil erosion, sand storms, biodiversity loss, solid waste management problems, and acid rain [1-4]. Urban haze, driven mainly by fossil fuel use, especially coal and hydrocarbons [5,6], imposes significant costs on individuals and China's health system. For example, in the Pearl River Delta Region that accounts for over 10\% of China's national gross domestic product (GDP), the total economic loss due to the health effects of $\mathrm{PM}_{10}$ (particulate matter whose diameter is below $10 \mu \mathrm{m}$ ) was estimated to be US $\$ 45$ billion, equivalent to $1.35 \%$ of the regional economy's GDP [7]. In haze-polluted environments, the World Health Organization estimated that respiratory disease caused the loss of 2.25 disability-adjusted life years per thousand people.

While pollution governance, in particular haze reduction, is the single most important focus of Chinese government environmental policy [8], haze reduction targets are frequently unmet, with 338 of China's largest cities experiencing, on average, deteriorating air quality between 2016 and 2017 [9]. Improved quality of life and health outcomes from haze reduction are tied to the interplay between the efficacy of public environmental policies and the public's willingness-to-pay (WTP) for haze governance. Considering the social and health harm of haze and the serious haze reduction burden, this paper measures the public's attitudes towards improving haze weather and what factors matter for their WTP for haze reduction. Selecting four cities in one of China's most haze prone provinces, the industrial province of Shandong, we analyzed the public's environmental awareness and its influence on their WTP for haze governance.

There have been various studies of WTP for haze reduction in China, including at the city level, such as Zibo and Jinan [10,11]; directly-controlled municipalities, including Chongqing [12], Beijing, and Shanghai [13]; the provincial level, such as Shandong and Fujian provinces [13]; regional areas, such as Beijing-Tianjin-Hebei [14] and the Yangtze River Delta [15]; and at the national level [16]. Zhou J et al. found that people in different cities had different WTP values for haze improvement in 2007 [17]. But, there is a research gap caused by the lack of comparative intercity studies assessing WTP levels across different cities within a single Chinese province. The lack of intra-province differences in WTP is surprising because environmental policy is mainly developed and implemented at the province level. Yet, policy makers have proceeded to design and implement policy lacking knowledge of any intercity WTP differences or the factors that might account for any such WTP differences. To ensure that haze governance projects are consciously endorsed and supported, policymakers need to address any intercity differences in public attitudes towards haze reduction, especially whether or not the public is willing to share the cost of smog governance. Only through a better understanding of any intercity differences in public preferences towards haze improvement, and securing public support for haze reduction policies, will sustainable provincial and national environmental policies, with their attendant health and social well-being benefits, be achieved.

\section{Study Design}

\subsection{Study Site, Sampling Technique, and Data Collection}

Our study site was Shandong province, a major east coast heavy industry province experiencing rapid industrialization and urbanization, with a GDP that was ranked third after Guangdong and Jiangsu and a per capita GDP that was ranked tenth in China in 2015 [18]. With a mix of chemical, auto, food processing, engineering, and machinery industries, coal consumption accounts for around $80 \%$ and crude oil consumption around $15 \%$ of Shandong's total energy consumption [18]. A combination of stratified sampling and non-probability sampling methods were used to collect the data. First, Shandong province's 17 cities were stratified into four clusters in terms of indicators comprising per capita GDP, a ratio of the income from the secondary sector to GDP, net income of rural residents, disposal income of urban residents, the number of private cars owned, and the number of heavy polluted days over a year. Second, a city was randomly selected in each stratification, yielding Jinan, 
Yantai, Zibo, and Linyi as our sampling cities. Face-to-face interviews with 1033 residents aged more than 18 years old were conducted at random in November 2014 at places attracting large crowds, such as supermarkets, squares, and gardens. There were 1006 usable questionnaires, with a valid response rate of $97.39 \%$. Face-to-face interviews have the advantage of ensuring good response rates to all questions and the exchange of information to reduce misunderstanding or misinterpreting the survey questions. The sample sizes in each city are presented in Table 1.

Air quality varied across the four cities. As shown in detailed air quality measures in Table 1 and Figure 1, the 2014 November air quality in Yantai was the best among the four cites, with Jinan in the middle and Zibo and Linyi being the worst. These intra-provincial differences reflected the industrial mix of the four cities and seasonality factors. Shandong's sizable agricultural sector meant that the traditional custom of burning-off the wheat or corn straw produced significant smoke in the harvest seasons and during winter, there was a significant rise in air pollution due to central coal heating. Considering these seasonality factors, we undertook the investigation in November.

Table 1. Sample sizes and air quality of the four cities in Shandong province (among 17 cities in November, 2014).

\begin{tabular}{|c|c|c|c|c|c|c|c|c|c|c|c|}
\hline \multirow[t]{2}{*}{ City } & \multirow[t]{2}{*}{$\begin{array}{c}\text { Population } \\
\text { (million) }\end{array}$} & \multirow[t]{2}{*}{$\begin{array}{l}\text { Area } \\
\left(\mathrm{km}^{2}\right)\end{array}$} & \multirow[t]{2}{*}{$\begin{array}{l}\text { GDP per } \\
\text { Capita } \\
\text { (US\$) }\end{array}$} & \multicolumn{2}{|c|}{$\begin{array}{c}\text { Average } \\
\text { Concentration of } \\
\text { Nitrogen Dioxide } \\
\left(\mu \mathrm{g} / \mathrm{m}^{3}\right)\end{array}$} & \multicolumn{2}{|c|}{$\begin{array}{c}\text { Average } \\
\text { Concentration } \\
\text { of } \mathrm{PM}_{10} \\
\left(\mu \mathrm{g} / \mathrm{m}^{3}\right)\end{array}$} & \multicolumn{2}{|c|}{$\begin{array}{c}\text { Average } \\
\text { Concentration } \\
\text { of } \mathrm{PM}_{2.5} \\
\left(\mu \mathrm{g} / \mathrm{m}^{3}\right)\end{array}$} & \multicolumn{2}{|c|}{$\begin{array}{c}\text { Days of } \\
\text { Visibility } \\
\text { over } 10 \mathrm{~m}\end{array}$} \\
\hline & & & & Value & No. & Value & No. & Value & No. & Value & No. \\
\hline Yantai & 6.64 & 13,746 & $12,477.79$ & 48 & 3 & 76 & 1 & 60 & 2 & 22 & 3 \\
\hline Jinan & 5.92 & 8177 & $11,645.03$ & 64 & 11 & 172 & 11 & 100 & 7 & 9 & 10 \\
\hline Zibo & 4.18 & 5965 & $12,870.96$ & 74 & 15 & 187 & 14 & 120 & 14 & 8 & 15 \\
\hline Linyi & 9.94 & 17,184 & 5109 & 74 & 16 & 189 & 15 & 115 & 13 & 8 & 16 \\
\hline
\end{tabular}

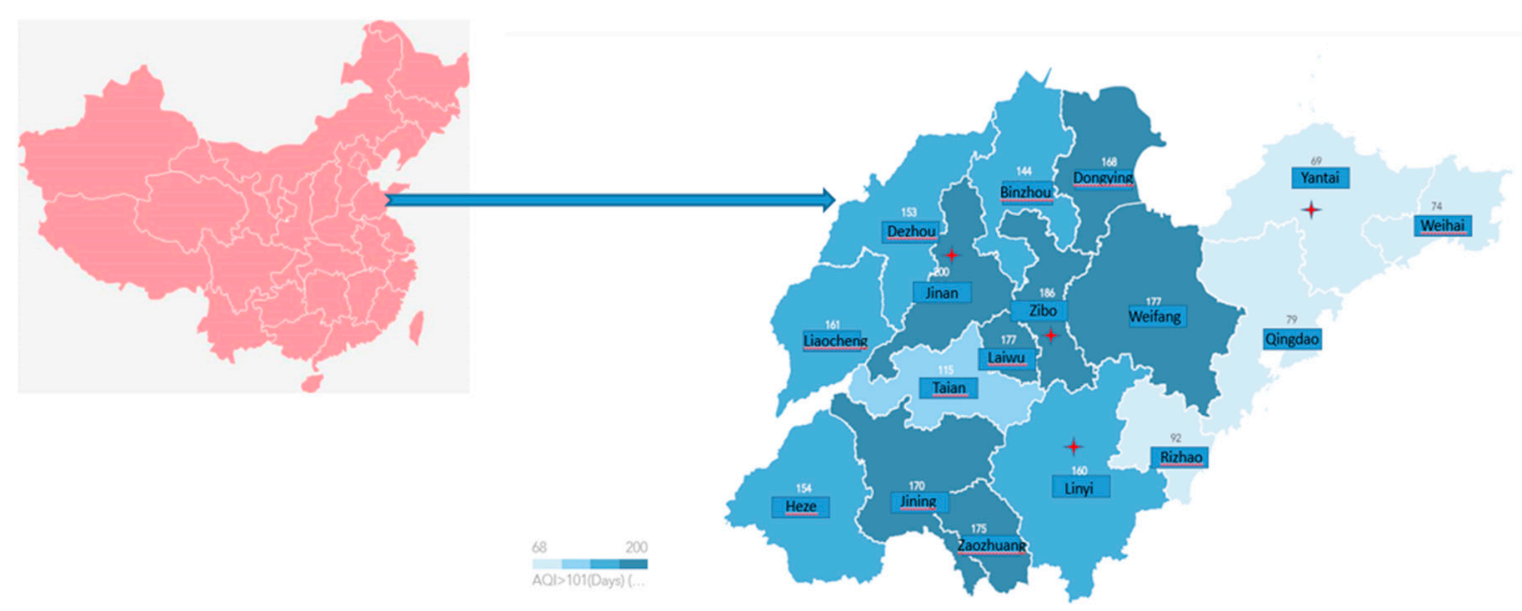

Figure 1. Air Quality Index > 101 days in Shandong (2014).

\subsection{Questionnaire and the CVM Survey}

A survey questionnaire addressed residents' attitude and behavior concerning haze governance in the four cities. The questionnaire consisted of four parts: (1) the residents' socioeconomic status, including gender, age, education, marital status, region of residence, occupation, and monthly income level; (2) the residents' knowledge and behavior regarding haze; (3) the residents' satisfaction and support for haze governance policies; and (4) the residents' WTP for improving the haze situation.

We employed the contingent valuation method (CVM) [19-22], which presents consumers with hypothetical opportunities to buy public goods, where the WTP for a given commodity is elicited directly through a survey, thus circumventing the absence of a real market for public goods [23]. 
We selected a realistic payment option in the CVM survey [24]. Respondents were presented with a hypothetical situation that provided full information on the haze problem, allowing them to reveal their values as accurately as possible. Figure 2 presents the diagrammatic of the open-ended hypothetical valuation questions. Respondents that were willing to pay, were then asked: "How much are you willing to pay?". Those who chose "unwillingness to pay" were asked for their reasons. To avoid any spurious emotions affecting responses, they were informed that the study was being carried out for academic purposes only.

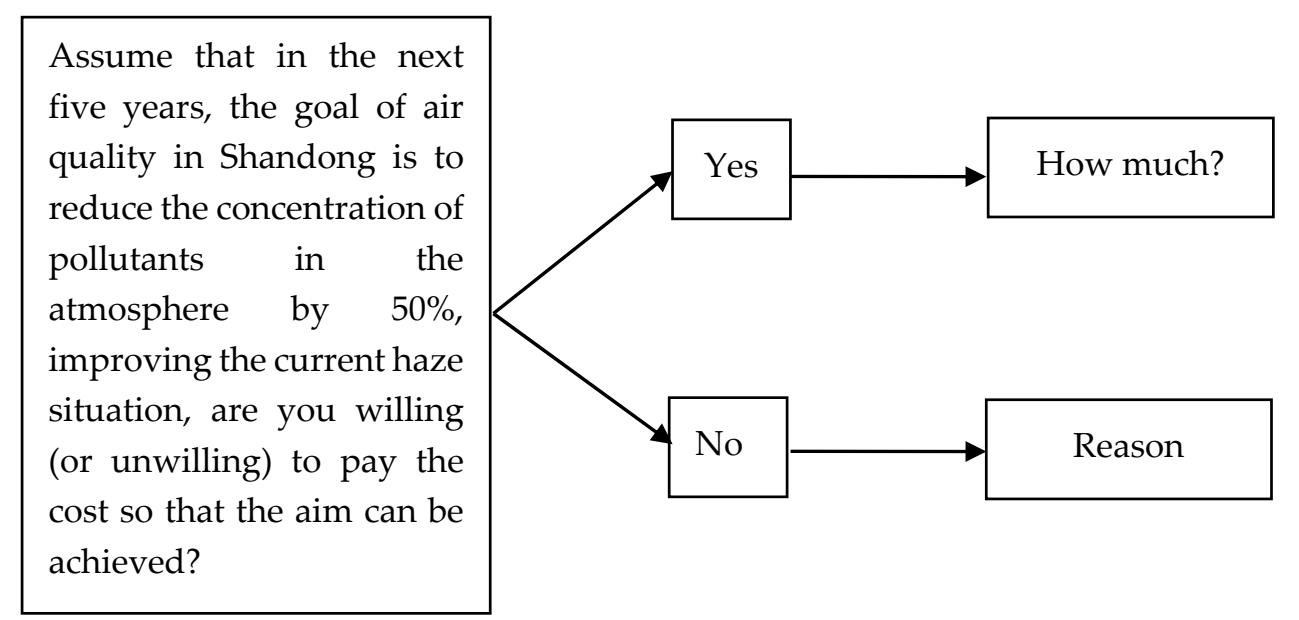

Figure 2. Main structure of the CVM survey.

\subsection{Measurement of Haze Attitudes}

\subsubsection{The Environmental Awareness and Confidence Indicators}

To assess respondents' haze understanding and haze behavior, an environmental awareness indicator was constructed. The indicator consisted of two parts: respondents' subjective perception of haze weather and respondents' objective concern and knowledge of haze weather. In the construction of the index, we used the Delphi method to consult 20 experts in the public health and environmental health area across five Chinese universities. As shown in Table 2, each index comprised four questions, measured by five-point and two-point severity scales. Aggregating the four subjective haze questions, the index ranged between 4 (lowest concern) and 20 (highest concern) points, where residents' subjective perception of haze weather was categorized as $4-5$ very good, $6-10$ good, 11-15 bad, and 16-20 very bad. The objective indicators of residents' knowledge of haze weather ranged from 2 to 12, with 2-3 labeled not concerned/understand, 4-6 little concern/understanding, 7-9 moderate concern/understanding, and 10-12 high concern/understanding.

Table 2. Environmental awareness indicators.

\begin{tabular}{|c|c|c|c|}
\hline Subjective Indicators & Options of Response & Objective Indicators & Options of Response \\
\hline $\begin{array}{l}\text { How would you rate the } \\
\text { haze weather situation in } \\
\text { your locality? }\end{array}$ & $\begin{array}{l}\text { Extremely serious }=5 \\
\text { Very serious }=4 \\
\text { Moderately serious }=3 \\
\text { A little serious }=2 \\
\text { Not serious }=1\end{array}$ & Do you know what haze is? & $\begin{array}{l}\text { Yes }=1 \\
\text { No }=0\end{array}$ \\
\hline $\begin{array}{l}\text { Were there times when } \\
\text { you experience haze } \\
\text { pollution in your } \\
\text { locality? }\end{array}$ & $\begin{array}{l}\text { Always }=5 \\
\text { Often }=4 \\
\text { Sometimes }=3 \\
\text { Rarely }=2 \\
\text { Never }=1\end{array}$ & $\begin{array}{l}\text { Do you know the causes of } \\
\text { haze weather? }\end{array}$ & $\begin{array}{l}\text { Totally }=5 \\
\text { A lot }=4 \\
\text { Moderately }=3 \\
\text { A little }=2 \\
\text { Not at all }=1\end{array}$ \\
\hline
\end{tabular}


Table 2. Cont.

\begin{tabular}{|c|c|c|c|}
\hline Subjective Indicators & Options of Response & Objective Indicators & Options of Response \\
\hline $\begin{array}{l}\text { How would you } \\
\text { evaluate air quality in } \\
\text { the fall and winter last } \\
\text { year? }\end{array}$ & $\begin{array}{l}\text { Very poor }=5 \\
\text { Poor }=4 \\
\text { Fair }=3 \\
\text { Good }=2 \\
\text { Very good }=1\end{array}$ & $\begin{array}{l}\text { Have you ever sought } \\
\text { knowledge on health } \\
\text { protection during haze } \\
\text { weather? }\end{array}$ & $\begin{array}{l}\text { Yes }=1 \\
\text { No }=0\end{array}$ \\
\hline $\begin{array}{l}\text { How would you rate the } \\
\text { influence of haze } \\
\text { weather on your daily } \\
\text { life? }\end{array}$ & $\begin{array}{l}\text { Major impact }=5 \\
\text { large impact }=4 \\
\text { medium impact }=3 \\
\text { small impact }=2 \\
\text { no impact }=1\end{array}$ & $\begin{array}{l}\text { Do you pay attention to your } \\
\text { local air quality index? }\end{array}$ & $\begin{array}{l}\text { Yes, completely = } 5 \\
\text { Yes, mostly }=4 \\
\text { Yes, a little }=3 \\
\text { No, not really = } 2 \\
\text { No, not at all = } 1\end{array}$ \\
\hline
\end{tabular}

\subsubsection{Confidence and Satisfaction in Government Indicator}

Table 3 displays the five-point satisfaction scale for five questions measuring residents' confidence and satisfaction in central and local government haze governance.

Table 3. Confidence and satisfaction in government indicators.

\begin{tabular}{lll}
\hline The Variables & Options of Response \\
\hline 1 & $\begin{array}{l}\text { Satisfied with the haze monitoring and prediction work of the central } \\
\text { government }\end{array}$ & Highly satisfied $=5$ \\
2 & Satisfied with the haze control work of the central government & Satisfied $=4$ \\
Satisfied with the haze monitoring and prediction work of the local & Neutral $=3$ \\
government & A little dissatisfied $=2$ \\
4 & Satisfied with the haze control work of the local government & Not satisfied $=1$ \\
& & \\
\hline & & Totally confident $=5$ \\
& The confidence of effectiveness of government policies about haze governance & Confident $=4$ \\
& Neutral $=3$ \\
& A little unconfident $=2$ \\
& Highly unconfident $=1$ \\
\hline
\end{tabular}

The government confidence and satisfaction indicators aggregated from 5 (lowest confidence in government) to 25 (highest confidence in government) points, which were then classified into four confidence/satisfaction with government groups: 5-10 no confidence/satisfaction; $11-15$ neutral; 16-20 confidence/satisfaction; and 21-25 high confidence/satisfaction.

\subsection{Statistical Tools and Analytical Models}

Survey-based data often have to cope with missing data. In our CVM survey, many respondents were unwilling to pay for improving the haze situation. Therefore, we lost these bidders when referring to the amount of cash WTP respondents selected. Further, high bidders may have observed and unobserved attributes. Specifically, higher income, younger, better educated respondents may be more likely to pay and to pay more for haze improvement than other respondents. Also, those who are willing to pay more for haze reduction may have stronger attitudes towards purchasing for air quality. Hence, the analysis of the determinants of respondents' WTP amount may potentially suffer from attitude-based selection bias. Specifically, parameter estimates of the determinants of the WTP (attitude) may be biased. One way we selected to control for this attitude-based selection bias was to jointly estimate the determinants of WTP and WTP amount.

Following the Heckman sample selection model [25], the latent relationship between respondents' attributes and choice of paying for improving the haze situation is modeled as:

$$
Z_{i}^{*}=W_{i}^{\prime} \gamma+\mu_{i}
$$


where $Z_{i}^{*}$ is the latent measure of an individual's WTP, $W_{i}{ }^{\prime}$ is a vector of characteristics for individual $i, \gamma$ is the corresponding vector of coefficients to be estimated, and $\mu_{i}$ is the random disturbance for individual $i$ [26]. The observed outcome is:

$$
\begin{cases}Z_{i}=1, & \text { if } Z_{i}^{*}>0 \\ Z_{i}=0, & \text { if } Z_{i}^{*} \leq 0\end{cases}
$$

However, information on the amount of WTP is only available if the purchase decision is reported by the respondents. Respondents' latent purchase amount is modeled as:

$$
Y_{i}^{*}=X_{i}^{\prime} \beta+\varepsilon_{i}
$$

where $Y_{i}$ is the dependent variable (the observed realization of another latent variable $Y_{i}^{*}$ ), which is observable if and only if $Z_{i}^{*}$ exceeds a certain threshold. In our case, $Y_{i}$ is the non-zero price elasticity of demand for haze improvement, $X_{i}{ }^{\prime}$ is a vector of covariates for individual $i, \beta$ is a vector of coefficients for the outcome equation, and $\varepsilon_{i}$ is a random disturbance term for individual $i$. The observed response to the question on "How much is you willing to pay?" is:

$$
\left\{\begin{array}{c}
Y_{i}=Y_{i}^{*}, \text { if } Z_{i} \neq 0 \\
Y_{i}=\text { missing, if } Z_{i}=0
\end{array}\right.
$$

Estimation of WTP choice with the sub-sample who provide a positive response on haze improvement is equivalent to:

$$
\begin{gathered}
E\left(Y \mid Z_{i}^{*}>0\right)=E\left(X_{i}^{\prime} \beta+\varepsilon_{i} \mid W_{i}^{\prime} \gamma+\mu_{i}>0\right)=E\left(X_{i}{ }^{\prime} \beta+\varepsilon_{i} / \mu_{i}>W_{i}{ }^{\prime} \gamma\right) \\
=X_{i}^{\prime} \beta+E\left(\varepsilon_{i} / \mu_{i}>-W_{i}^{\prime} \gamma\right)=X_{i}^{\prime} \beta+\rho \sigma \varepsilon \lambda\left(-W_{i}{ }^{\prime} \gamma\right)
\end{gathered}
$$

Assume $E\left(\varepsilon_{i}\right)=E\left(\mu_{i}\right)=0$, and $\rho=\operatorname{corr}\left(\varepsilon_{i}, \mu_{i}\right)$

The model assumed that the error terms have a bivariate normal distribution with zero means and correlation rho $(\rho)$, where the significance of the $\rho(\rho=0)$ was used to infer that $Z^{*}$ and $Y^{*}$ are correlated, and there was a sample selection problem. In our case, a significant rho statistic indicates whether there are unobservable factors affecting an individual's WTP that were correlated with the price sensitivity of haze attitude.

Statistical packages Stata12.0 (StataCorp LP., College Station, TX, USA) and SPSS 17.0 (SPSS Inc., Chicago, IL, USA) were employed to estimate the models.

\section{Results}

Table 4 reports the descriptive statistics for the main socio-economic characteristics and haze awareness and confidence of the sample respondents in the four cities. The respondents were evenly distributed between male (51.6\%) and female (48.4\%), with a mean age of 37 years, and slightly skewed towards the younger age groups, especially for Linyi. For the income level, over $50 \%$ of respondents earn less than US $\$ 465.84$ (CNY3000) per month, which is lower than the US\$670.61 (CNY4318.75) average monthly wage level in Shandong province (see Table 4). In terms of marital status, $70 \%$ of the respondents were single, reflecting the young age distribution of the sample. With $99 \%$ respondents educated, Table 4 shows that the respondents in Yantai were better educated than the other cities, with over $80 \%$ respondents having at least a high school education. About $50 \%$ of respondents were office workers or public servants, $17 \%$ were self-employed, and $11 \%$ were students, reflecting the bias toward urban white-collar workers, which also explains the lower than average Shandong monthly wage, especially in Linyi. In short, the respondents were more likely to be young and educated, but with a lower monthly income than the average Shandong resident. 
Table 4. Socio-economic characteristics and haze attitudes of the respondents $(N=1006)$.

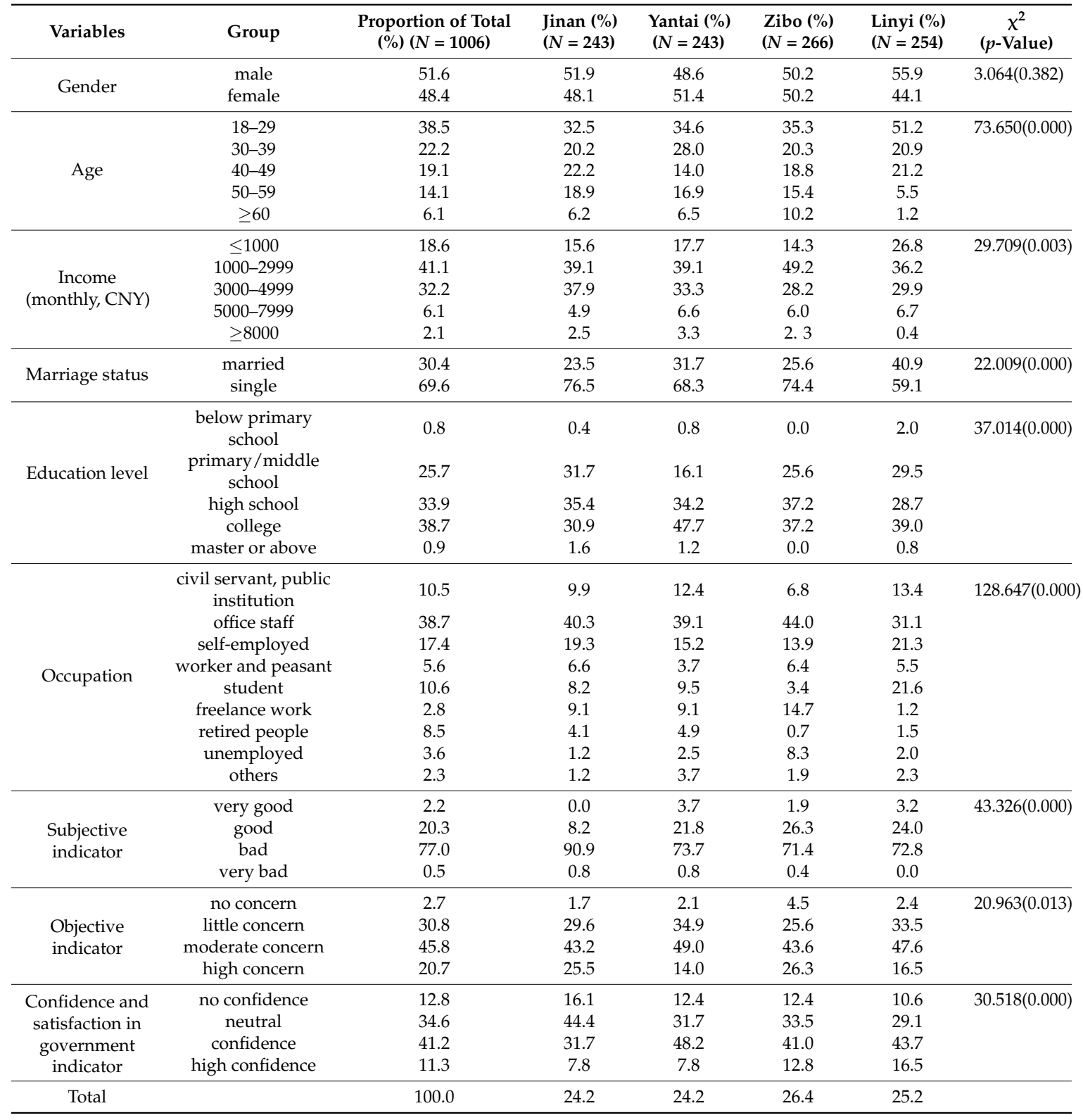

As for haze awareness and confidence, there were significant variations in haze attitudes across the four cities (at $p=0.05$ level). In Table 4 , Jinan had the largest percentage of respondents with a "bad" (91\%) subjective haze assessment and "no confidence and satisfaction" $(16 \%)$ in the government, compared to about $72 \%$ with a "bad" subjective haze assessment in the other cities. Zibo had the largest percentage (26\%) of respondents who had "high concern" with haze and Yantai had the lowest percentage $(14 \%)$ with a "high concern" with haze.

In Table 5, using the Heckman model, we analyzed the difference in WTP amount across the four cities and in Table 6, we presented the socio-economic characteristics and haze attitudes toward people with positive WTP. As shown in Table 5, Rho $(\rho=0)$ was significant, which meant that the WTP amount was associated with several characteristics that affect their WTP. Specifically, there were significant differences in WTP across the four cities: Yantai, Zibo, and Linyi were more willing to pay for haze improvement than Jinan residents (at the $p=0.001$ level). Further, Table 5 shows the common patterns found in previous studies related to age, trust of government, haze attitudes, income, education, and haze knowledge. Respondents' WTP amount was negative for those over 40 years old, 
but positive for 18-30-year-old respondents, and also negative for those with incomes below US\$155.28 (CNY1000).

Table 5. Heckman sample selection model analysis $(N=1006)$. (Wald $\left.\mathrm{Chi}^{2}=70.37, P=0.000\right)$.

\begin{tabular}{|c|c|c|c|c|c|}
\hline \multirow{2}{*}{\multicolumn{2}{|c|}{ Independent Variables }} & \multicolumn{2}{|c|}{$\begin{array}{l}\text { (1) Outcome Part } \\
\text { Log (WTP amount) }\end{array}$} & \multicolumn{2}{|c|}{$\begin{array}{l}\text { (2) Selection Part } \\
\text { WTP }\end{array}$} \\
\hline & & $\begin{array}{l}\text { Parameter } \\
\text { Estimate }\end{array}$ & $p$-Value & $\begin{array}{l}\text { Parameter } \\
\text { Estimate }\end{array}$ & $p$-Value \\
\hline \multicolumn{6}{|l|}{ Social-economic information } \\
\hline Age $(1=18-30)$ & $\begin{array}{l}2=30-40 \\
3=40-50 \\
4=50-60 \\
5=\text { over } 60\end{array}$ & $\begin{array}{l}-0.785 \\
-1.046^{* *} \\
-1.393^{* *} \\
-0.842\end{array}$ & $\begin{array}{l}0.276 \\
0.049 \\
0.032 \\
0.358\end{array}$ & $\begin{array}{l}-0.255^{*} \\
-0.193 \\
-0.260 \\
-0.089\end{array}$ & $\begin{array}{l}0.091 \\
0.155 \\
0.180 \\
0.267\end{array}$ \\
\hline City (1 = Jinan) & $\begin{array}{l}2=\text { Yantai } \\
3=\text { Zibo } \\
4=\text { Linyi }\end{array}$ & $\begin{array}{l}0.909 \\
0.833 \\
0.743\end{array}$ & $\begin{array}{l}0.124 \\
0.799 \\
0.812\end{array}$ & $\begin{array}{l}0.421^{* * *} \\
0.570^{* * *} \\
0.500^{* * *}\end{array}$ & $\begin{array}{l}0.005 \\
0.003 \\
0.000\end{array}$ \\
\hline Gender ( 1 = female $)$ & $2=$ male & -0.266 & 0.313 & -0.104 & 0.252 \\
\hline $\begin{array}{l}\text { Occupation } \\
\text { (1=civil servant, } \\
\text { public institution) }\end{array}$ & $\begin{array}{l}2=\text { office staff } \\
3=\text { self-employed } \\
4=\text { worker and peasant } \\
5=\text { student } \\
6=\text { freelance work } \\
7=\text { retired people } \\
8=\text { unemployed } \\
9=\text { others }\end{array}$ & $\begin{array}{c}-0.274 \\
0.031 \\
-0.326 \\
1.859 \\
-0.637 \\
-0.087 \\
0.146 \\
0.152\end{array}$ & $\begin{array}{l}0.216 \\
0.124 \\
0.217 \\
0.124 \\
0.569 \\
0.167 \\
0.783 \\
0.290\end{array}$ & $\begin{array}{c}-0.017 \\
0.295^{*} \\
0.072 \\
0.810^{* * *} \\
-0.215 \\
0.353 \\
0.024 \\
0.545\end{array}$ & $\begin{array}{c}0.913 \\
0.000^{* * *} \\
0.102 \\
0.000 \\
0.351 \\
0.283 \\
0.997 \\
0.789\end{array}$ \\
\hline $\begin{array}{l}\text { Monthly income } \\
(1=\text { below } 1000)\end{array}$ & $\begin{array}{l}2=1000-2999 \\
3=3000-4999 \\
4=5000-7999 \\
5=\text { over } 8000\end{array}$ & $\begin{array}{c}1.426 \\
2.191 \\
1.857 * * \\
1.513\end{array}$ & $\begin{array}{l}0.218 \\
0.122 \\
0.032 \\
0.290\end{array}$ & $\begin{array}{c}0.473^{* *} \\
0.689^{* * *} \\
0.315 \\
0.626^{*}\end{array}$ & $\begin{array}{l}0.020 \\
0.002 \\
0.191 \\
0.089\end{array}$ \\
\hline Marriage (1 = single) & $2=$ married & 0.177 & 0.340 & 0.006 & 0.496 \\
\hline $\begin{array}{l}\text { Education } \\
(1 \text { = below primary school) }\end{array}$ & $\begin{array}{l}2=\text { primary } / \text { middle } \\
\text { school } \\
3=\text { high school } \\
4=\text { college } \\
5=\text { master or above }\end{array}$ & $\begin{array}{l}0.858 \\
0.560 \\
0.283 \\
0.168\end{array}$ & $\begin{array}{l}0.415 \\
0.323 \\
0.186\end{array}$ & $\begin{array}{l}1.158^{* *} \\
1.039^{*} \\
0.926 \\
1.154\end{array}$ & $\begin{array}{l}0.062 \\
0.101 \\
0.154\end{array}$ \\
\hline \multicolumn{6}{|c|}{ Environmental awareness and confidence indicators } \\
\hline $\begin{array}{l}\text { Objective indicators } \\
(1=\text { not concern })\end{array}$ & $\begin{array}{l}2=\text { little concern } \\
3=\text { moderate concern } \\
4=\text { high concern }\end{array}$ & $\begin{array}{l}-0.093 \\
0.442 \\
1.004\end{array}$ & $\begin{array}{l}0.130 \\
0.400 \\
0.737\end{array}$ & $\begin{array}{l}0.644^{* *} \\
0.752^{* *} \\
0.951^{* * *}\end{array}$ & $\begin{array}{l}0.036 \\
0.016 \\
0.003\end{array}$ \\
\hline $\begin{array}{l}\text { Confidence and satisfaction } \\
\text { in government indicators } \\
(1=\text { no confidence })\end{array}$ & $\begin{array}{l}2=\text { neutral confidence } \\
3=\text { confidence high } \\
4=\text { confidence }\end{array}$ & $\begin{array}{l}0.389 \\
0.523 \\
1.004\end{array}$ & $\begin{array}{l}0.720 \\
0.721 \\
0.773\end{array}$ & $\begin{array}{c}0.208 \\
0.423^{* * *} \\
0.680^{* * *}\end{array}$ & $\begin{array}{l}0.140 \\
0.002 \\
0.000\end{array}$ \\
\hline $\begin{array}{l}\text { Subjective indicators } \\
(1 \text { = Very good })\end{array}$ & $\begin{array}{l}2=\text { good } \\
3=\text { bad } \\
4=\text { very bad }\end{array}$ & $\begin{array}{l}-0.064 \\
-0.065 \\
1.804\end{array}$ & $\begin{array}{l}0.363 \\
0.214 \\
0.891\end{array}$ & $\begin{array}{c}0.349 \\
0.470 \\
1.494^{* *}\end{array}$ & $\begin{array}{l}0.247 \\
0.121 \\
0.046\end{array}$ \\
\hline \multicolumn{2}{|c|}{ Constant } & -0.285 & 0.128 & $-1.345^{*}$ & 0.057 \\
\hline \multicolumn{2}{|c|}{ Rho $(\rho=0)$} & \multicolumn{2}{|c|}{$\mathrm{Chi}^{2}=5.21$} & \multicolumn{2}{|c|}{$P=0.0225$} \\
\hline
\end{tabular}

Note: ${ }^{*}$ indicate significance at the $p=0.10$ level, ${ }^{* *}$ indicate significance at the $p=0.05$ level, ${ }^{* * *}$ indicate significance at the $p=0.001$ level.

Table 6 displays the details of the WTP across the four cities: 55.51\% respondents in Linyi were willing to pay for haze governance, followed by Yantai (48.56\%), Zibo (51.12\%), and Jinan (33.33\%). Respondent age was a significant factor (test statistic $\chi^{2}=26.42, p$-value $<0.05$ ) in the willingness to pay for haze improvement, with over $60 \%$ of the respondents under 40 years old willing to pay for haze improvement. Importantly, different age groups across the four cities had a different WTP. 
Further, respondents in different income levels $\left(\chi^{2}=31.61, p\right.$-value $\left.<0.001\right)$ had a significantly different WTP across the four cities. As shown in Table 6, there were also significantly different subjective indicators across the four cities, with $93.83 \%$ respondents in Jinan feeling "bad" about the haze situation compared to $73.73 \%$ in Yantai, 74.26 in Zibo, and $78.01 \%$ in Linyi.

Table 6. Socio-economic characteristics and haze attitudes toward people with positive WTP.

\begin{tabular}{|c|c|c|c|c|c|c|}
\hline Variables & Jinan $(n=81)$ & Yantai $(n=118)$ & Zibo $(n=136)$ & Linyi $(n=141)$ & $x^{2}$ & $\rho$ \\
\hline \multicolumn{7}{|l|}{ Gender } \\
\hline Male & $44(54.32 \%)$ & $57(48.31 \%)$ & $67(49.26 \%)$ & $72(51.06 \%)$ & \multirow{2}{*}{0.80} & \multirow{2}{*}{0.849} \\
\hline Female & $37(45.68 \%)$ & $61(51.69 \%)$ & $69(50.74 \%)$ & $69(48.94 \%)$ & & \\
\hline \multicolumn{7}{|l|}{ Age } \\
\hline$<30$ & $35(43.21 \%)$ & $48(40.68 \%)$ & $60(44.12 \%)$ & $81(57.45 \%)$ & \multirow{5}{*}{26.42} & \multirow{5}{*}{0.009} \\
\hline $30-40$ & $18(22.22 \%)$ & $32(27.12 \%)$ & $29(21.32 \%)$ & $29(20.57 \%)$ & & \\
\hline $40-50$ & $16(19.75 \%)$ & $15(12.71 \%)$ & $24(17.65 \%)$ & $25(17.73 \%)$ & & \\
\hline $50-60$ & $10(12.35 \%)$ & $13(11.02 \%)$ & $13(9.56 \%)$ & $6(4.26 \%)$ & & \\
\hline$>60$ & $2(2.47 \%)$ & $10(8.47 \%)$ & $10(7.35 \%)$ & $0(0.00 \%)$ & & \\
\hline \multicolumn{7}{|l|}{ Income } \\
\hline$<1000$ & $13(16.05 \%)$ & $23(19.49 \%)$ & $12(8.82 \%)$ & $43(30.50 \%)$ & \multirow{5}{*}{31.61} & \multirow{5}{*}{0.002} \\
\hline 1000-2999 & $29(35.80 \%)$ & $40(33.90 \%)$ & $65(47.79 \%)$ & $50(35.46 \%)$ & & \\
\hline 3000-4999 & $35(43.21 \%)$ & $45(38.14 \%)$ & $45(33.09 \%)$ & $42(29.79 \%)$ & & \\
\hline 5000-7999 & $2(2.47 \%)$ & $7(5.93 \%)$ & $9(6.62 \%)$ & $6(4.26 \%)$ & & \\
\hline$>8000$ & $2(2.47 \%)$ & $3(2.54 \%)$ & $5(3.68 \%)$ & $0(0.00 \%)$ & & \\
\hline \multicolumn{7}{|l|}{ Education } \\
\hline below primary school & $0(0.00 \%)$ & $2(1.69 \%)$ & $0(0.00 \%)$ & $4(2.84 \%)$ & \multirow[t]{5}{*}{17.81} & \multirow[t]{5}{*}{0.122} \\
\hline primary/middle school & $16(19.75 \%)$ & $16(13.56 \%)$ & $28(20.59 \%)$ & $37(26.24 \%)$ & & \\
\hline high school & $29(35.80 \%)$ & $37(31.36 \%)$ & $53(38.97 \%)$ & $38(26.95 \%)$ & & \\
\hline college & $35(43.21 \%)$ & $62(52.54 \%)$ & $55(40.44 \%)$ & $61(43.26 \%)$ & & \\
\hline master or above & $1(1.23 \%)$ & $1(0.85 \%)$ & $0(0.00 \%)$ & $1(0.71 \%)$ & & \\
\hline \multicolumn{7}{|l|}{ Marriage status } \\
\hline married & $27(33.33 \%)$ & $42(35.59 \%)$ & $39(28.68 \%)$ & $62(43.97 \%)$ & \multirow[t]{2}{*}{7.32} & \multirow[t]{2}{*}{0.062} \\
\hline single & $54(66.67 \%)$ & $76(64.41 \%)$ & $97(71.32 \%)$ & $79(56.03 \%)$ & & \\
\hline \multicolumn{7}{|l|}{ Occupation } \\
\hline civil servant, public institution & $6(7.41 \%)$ & $16(13.56 \%)$ & $10(7.35 \%)$ & $19(13.48 \%)$ & \multirow[t]{9}{*}{65.45} & \multirow[t]{9}{*}{0.000} \\
\hline office staff & $33(40.74 \%)$ & $43(36.44 \%)$ & $64(47.06 \%)$ & $37(26.24 \%)$ & & \\
\hline self-employed & $18(22.22 \%)$ & $19(16.10 \%)$ & $23(16.91 \%)$ & $29(20.57 \%)$ & & \\
\hline worker and peasant & $3(3.70 \%)$ & $4(3.39 \%)$ & $9(6.62 \%)$ & $7(4.96 \%)$ & & \\
\hline student & $12(14.81 \%)$ & $15(12.71 \%)$ & $6(4.41 \%)$ & $38(26.95 \%)$ & & \\
\hline freelance work & $4(4.94 \%)$ & $9(7.63 \%)$ & $16(11.76 \%)$ & $1(0.71 \%)$ & & \\
\hline retired people & $5(6.17 \%)$ & $4(3.39 \%)$ & $1(0.74 \%)$ & $3(2.13 \%)$ & & \\
\hline unemployed & $0(0.00 \%)$ & $3(2.54 \%)$ & $4(2.94 \%)$ & $3(2.13 \%)$ & & \\
\hline others & $0(0.00 \%)$ & $5(4.24 \%)$ & $3(2.21 \%)$ & $4(2.84 \%)$ & & \\
\hline \multicolumn{7}{|l|}{ Subjective indicator } \\
\hline very good & $0(0.00 \%)$ & $2(1.69 \%)$ & $2(1.47 \%)$ & $3(2.13 \%)$ & 21.29 & 0.011 \\
\hline good & $3(3.70 \%)$ & $28(23.73 \%)$ & $32(23.53 \%)$ & $28(19.86 \%)$ & & \\
\hline bad & $76(93.83 \%)$ & $87(73.73 \%)$ & $101(74.26 \%)$ & $110(78.01 \%)$ & & \\
\hline very bad & $2(2.47 \%)$ & $1(0.85 \%)$ & $1(0.74 \%)$ & $0(0.00 \%)$ & & \\
\hline Objective indicator & & & & & & \\
\hline not concern & $0(0.00 \%)$ & $2(1.69 \%)$ & $3(2.21 \%)$ & $2(1.42 \%)$ & 15.64 & 0.075 \\
\hline little concern & $16(19.75 \%)$ & $36(30.51 \%)$ & $32(23.53 \%)$ & $44(31.21 \%)$ & & \\
\hline moderate concern & $35(43.21 \%)$ & $57(48.31 \%)$ & $63(46.32 \%)$ & $70(49.65 \%)$ & & \\
\hline high concern & $30(37.04 \%)$ & $23(19.49 \%)$ & $38(27.94 \%)$ & $25(17.73 \%)$ & & \\
\hline Confidence and satisfaction in $\mathrm{g}$ & ernment indicat & & & & & \\
\hline no confidence & $7(8.64 \%)$ & $12(10.17 \%)$ & $18(13.24 \%)$ & $7(4.96 \%)$ & 12.42 & 0.191 \\
\hline neutral & $30(37.04 \%)$ & $39(33.05 \%)$ & $40(29.41 \%)$ & $37(26.24 \%)$ & & \\
\hline confidence & $33(40.74 \%)$ & $53(44.92 \%)$ & $62(45.59 \%)$ & $69(48.94 \%)$ & & \\
\hline high confidence & $11(13.58 \%)$ & $14(11.86 \%)$ & $16(11.76 \%)$ & $28(19.86 \%)$ & & \\
\hline $\mathrm{N}$ & 243 & 243 & 266 & 254 & & \\
\hline $\mathrm{n} / \mathrm{N}(\%)$ & $33.33 \%$ & $48.56 \%$ & $51.12 \%$ & $55.51 \%$ & & \\
\hline WTP amount(mean) & CNY72.12 & CNY95.96 & CNY83.99 & CNY104.64 & & \\
\hline
\end{tabular}


The major reasons for respondents' unwillingness to pay for haze improvement are presented in Table 7. About two thirds of the non-payers argued that air quality improvement was mainly the responsibility of governments (39\%) and polluters (25\%), instead of ordinary citizens, but $27 \%$ said that their income was too low to contribute to a pollution tax and $6 \%$ claimed that they did not believe the funds would be used effectively for environmental conservation. There were significant differences across cities. Non-payers in Zibo (43.85\%) Jinan (42.50\%), and Yantai (41.94\%) thought the government should pay for haze reduction, but a significantly lower percentage of Linyi respondents thought this (26.55\%). Linyi had a significantly larger proportion of respondents $(35.40 \%)$ who thought polluters should pay for haze reduction. In terms of income being too low to afford haze reduction, Zibo had the largest proportion of non-payers (33.08\%), followed by Jinan (30.63\%) and Linyi $(29.20 \%)$, with Yantai $(15.32 \%)$ having the lowest proportion. Yantai $(11.29 \%)$ and Linyi $(7.96 \%)$ were significantly more concerned than the other cities on how haze reduction funds might be effectively used.

Table 7. Respondents' reasons for not paying.

\begin{tabular}{|c|c|c|c|c|c|c|}
\hline Reasons for not Paying & $\begin{array}{l}\text { Jinan }(\%) \\
(n=160)\end{array}$ & $\begin{array}{l}\text { Yantai }(\%) \\
(n=124)\end{array}$ & $\begin{array}{l}\text { Zibo (\%) } \\
(n=130)\end{array}$ & $\begin{array}{l}\text { Linyi }(\%) \\
(n=113)\end{array}$ & $x^{2}$ & $p$ \\
\hline Should be paid by government & 42.50 & 41.94 & 43.85 & 26.55 & \multirow{7}{*}{46.50} & \multirow{7}{*}{0.000} \\
\hline Income is too low to afford it & 30.63 & 15.32 & 33.08 & 29.20 & & \\
\hline Who pollute the environment should pay & 23.75 & 29.84 & 15.38 & 35.40 & & \\
\hline $\begin{array}{l}\text { Worry about whether funds would be used } \\
\text { for environment conservation effectively }\end{array}$ & 3.13 & 11.29 & 3.85 & 7.96 & & \\
\hline Air quality is not bad & 0.00 & 1.61 & 1.54 & 0.88 & & \\
\hline Other reasons & 0.00 & 0.00 & 2.31 & 0.00 & & \\
\hline Total & 100.00 & 100.00 & 100.00 & 100.00 & & \\
\hline
\end{tabular}

As shown in Table 8, there were significant variations in non-payer's socio-economic characteristics and haze attitudes across the four cities. Jinan had the largest percentage of non-payers, with respondents being older and less educated, and having a "bad" perception of the haze situation and less confidence in the government compared to respondents in the other cities. Specifically, about $50 \%$ non-payers in Jinan were over the age of 40 , and $38.27 \%$ did not have a high school or more advanced education. Jinan had the largest number of non-payers feeling bad about the haze situation.

Table 8. Socio-economic characteristics and haze attitudes toward non-payers.

\begin{tabular}{|c|c|c|c|c|c|c|}
\hline Variables & Jinan $(n=162)$ & Yantai $(n=125)$ & Zibo $(n=129)$ & Linyi $(n=113)$ & $x^{2}$ & $P$ \\
\hline \multicolumn{7}{|l|}{ Gender } \\
\hline Male & $80(49.38 \%)$ & $64(51.20 \%)$ & $64(49.23 \%)$ & $43(38.05 \%)$ & \multirow{2}{*}{5.11} & \multirow{2}{*}{0.164} \\
\hline Female & $82(50.62 \%)$ & $61(48.80 \%)$ & $66(50.77 \%)$ & $70(61.95 \%)$ & & \\
\hline \multicolumn{7}{|l|}{ Age } \\
\hline$<30$ & $53(32.72 \%)$ & $44(35.20 \%)$ & $40(30.77 \%)$ & $59(52.21 \%)$ & \multirow{5}{*}{53.43} & \multirow{5}{*}{0.000} \\
\hline $30-40$ & $29(17.90 \%)$ & $38(30.40 \%)$ & $23(17.69 \%)$ & $29(25.66 \%)$ & & \\
\hline $40-50$ & $43(26.54 \%)$ & $18(14.40 \%)$ & $31(23.85 \%)$ & $23(20.35 \%)$ & & \\
\hline $50-60$ & $29(17.90 \%)$ & $21(16.80 \%)$ & $21(16.15 \%)$ & $1(0.88 \%)$ & & \\
\hline$>60$ & $8(4.94 \%)$ & $4(3.20 \%)$ & $15(11.54 \%)$ & $1(0.88 \%)$ & & \\
\hline \multicolumn{7}{|l|}{ Income } \\
\hline$<1000$ & $25(15.43 \%)$ & $20(16.00 \%)$ & $26(20.00 \%)$ & $25(22.12 \%)$ & \multirow{5}{*}{14.79} & \multirow{5}{*}{0.253} \\
\hline 1000-2999 & $66(40.74 \%)$ & $55(44.00 \%)$ & $66(50.77 \%)$ & $42(37.17 \%)$ & & \\
\hline $3000-4999$ & $57(35.19 \%)$ & $36(28.80 \%)$ & $30(23.08 \%)$ & $34(30.09 \%)$ & & \\
\hline 5000-7999 & $10(6.17 \%)$ & $9(7.20 \%)$ & $7(5.38 \%)$ & $11(9.73 \%)$ & & \\
\hline$>8000$ & $4(2.47 \%)$ & $5(4.00 \%)$ & $1(0.77 \%)$ & $1(0.88 \%)$ & & \\
\hline \multicolumn{7}{|l|}{ Education } \\
\hline below primary school & $1(0.62 \%)$ & $0(0.00 \%)$ & $0(0.00 \%)$ & $1(0.88 \%)$ & \multirow[t]{2}{*}{21.52} & \multirow[t]{2}{*}{0.043} \\
\hline primary/middle school & $61(37.65 \%)$ & $23(18.40 \%)$ & $40(30.77 \%)$ & $38(33.63 \%)$ & & \\
\hline
\end{tabular}


Table 8. Cont.

\begin{tabular}{|c|c|c|c|c|c|c|}
\hline Variables & Jinan $(n=162)$ & Yantai $(n=125)$ & Zibo $(n=129)$ & Linyi $(n=113)$ & $x^{2}$ & $P$ \\
\hline high school & $57(35.19 \%)$ & $46(36.80 \%)$ & $46(35.38 \%)$ & $35(30.97 \%)$ & & \\
\hline college & $40(24.69 \%)$ & $54(43.20 \%)$ & $44(33.85 \%)$ & $38(33.63 \%)$ & & \\
\hline master or above & $3(1.85 \%)$ & $2(1.60 \%)$ & $0(0.00 \%)$ & $1(0.88 \%)$ & & \\
\hline \multicolumn{7}{|l|}{ Marriage status } \\
\hline married & $132(81.48 \%)$ & $90(72.00 \%)$ & $101(77.69 \%)$ & $71(62.83 \%)$ & 13.30 & 0.004 \\
\hline single & $30(18.52 \%)$ & $35(28.00 \%)$ & $29(22.31 \%)$ & $42(37.17 \%)$ & & \\
\hline \multicolumn{7}{|l|}{ Occupation } \\
\hline $\begin{array}{l}\text { civil servant, public } \\
\text { institution }\end{array}$ & $18(11.11 \%)$ & $14(11.20 \%)$ & $8(6.15 \%)$ & $15(13.27 \%)$ & 79.71 & 0.000 \\
\hline office staff & $65(40.12 \%)$ & $52(41.60 \%)$ & $53(40.77 \%)$ & $42(37.17 \%)$ & & \\
\hline self-employed & $29(17.90 \%)$ & $18(14.40 \%)$ & $14(10.77 \%)$ & $25(22.12 \%)$ & & \\
\hline worker and peasant & $13(8.02 \%)$ & $5(4.00 \%)$ & $8(6.15 \%)$ & $7(6.19 \%)$ & & \\
\hline student & $8(4.94 \%)$ & $8(6.40 \%)$ & $3(2.31 \%)$ & $17(15.04 \%)$ & & \\
\hline freelance work & $18(11.11 \%)$ & $13(10.40 \%)$ & $23(17.69 \%)$ & $2(1.77 \%)$ & & \\
\hline retired people & $5(3.09 \%)$ & $8(6.40 \%)$ & $1(0.77 \%)$ & $1(0.88 \%)$ & & \\
\hline unemployed & $3(1.85 \%)$ & $3(2.40 \%)$ & $18(13.85 \%)$ & $2(1.77 \%)$ & & \\
\hline others & $3(1.85 \%)$ & $4(3.20 \%)$ & $2(1.54 \%)$ & $2(1.77 \%)$ & & \\
\hline \multicolumn{7}{|l|}{ Subjective indicator } \\
\hline very good & $0(0.00 \%)$ & $7(5.60 \%)$ & $3(2.31 \%)$ & $5(4.42 \%)$ & 33.92 & 0.000 \\
\hline good & 17 (10.49\%) & $26(20.80 \%)$ & $37(28.46 \%)$ & $33(29.20 \%)$ & & \\
\hline bad & $145(89.51 \%)$ & $91(72.80 \%)$ & $90(69.23 \%)$ & $75(66.37 \%)$ & & \\
\hline very bad & $0(0.00 \%)$ & $1(0.80 \%)$ & $0(0.00 \%)$ & $0(0.00 \%)$ & & \\
\hline \multicolumn{7}{|l|}{ Objective indicator } \\
\hline not concern & $4(2.47 \%)$ & $5(4.00 \%)$ & $9(6.92 \%)$ & $4(3.54 \%)$ & 13.27 & 0.151 \\
\hline little concern & $55(33.95 \%)$ & $47(37.60 \%)$ & $36(27.69 \%)$ & $42(37.17 \%)$ & & \\
\hline moderate concern & $71(43.83 \%)$ & $60(48.00 \%)$ & $55(42.31 \%)$ & $50(44.25 \%)$ & & \\
\hline high concern & $32(19.75 \%)$ & $13(10.40 \%)$ & $30(23.08 \%)$ & $17(15.04 \%)$ & & \\
\hline \multicolumn{7}{|c|}{ Confidence and satisfaction in government indicator } \\
\hline no confidence & $32(19.75 \%)$ & $18(14.40 \%)$ & $15(11.54 \%)$ & $20(17.70 \%)$ & 26.37 & 0.002 \\
\hline neutral & $78(48.15 \%)$ & $40(32.00 \%)$ & $47(36.15 \%)$ & $37(32.74 \%)$ & & \\
\hline confidence & $44(27.16 \%)$ & $60(48.00 \%)$ & $52(40.00 \%)$ & $42(37.17 \%)$ & & \\
\hline high confidence & $8(4.94 \%)$ & $7(5.60 \%)$ & $16(12.31 \%)$ & $14(12.39 \%)$ & & \\
\hline $\mathrm{N}$ & 243 & 243 & 266 & 254 & & \\
\hline $\mathrm{n} / \mathrm{N}(\%)$ & $66.67 \%$ & $51.44 \%$ & $48.88 \%$ & $44.49 \%$ & & \\
\hline
\end{tabular}

\section{Discussion}

Given its industrial structure and rural-urban composition, the four cities studied in Shandong are typical of industrializing China $[27,28]$. Therefore, our analysis and results are comparable to other parts of transitioning China. In each city, an overwhelming majority of respondents were concerned about haze pollution, but only a minority of respondents were willing to pay for haze governance, and, for those WTP, the WTP amount varied across the four cities due to age and income. These differences were significant.

The socio-economic structure of each city had an impact on the WTP. For example, age interacted with respondents' income and education level, with older, poorer, less educated, and less environmentally aware respondents less willing to pay and less willing to pay large amounts for haze reduction. Linyi had the highest WTP respondents under the age of 40, while Jinan had the highest WTP respondents over the age of 40 among the four cities, which may indicate that positive WTP in different cities reflected different age distributions, so policy makers need to consider different age distributions when setting environmental policy. 
Second, income had a positive impact on WTP for haze governance, but WTP varied across the four cities by income level. Only 15.32\% of non-payers in Yantai reported that their income was too low to afford haze reduction levies, representing about half the percentage of the other three cities.

Third, respondents' subjective feelings toward their local haze differed across the four cities. Jinan had the lowest WTP respondents among the four cities $(33.33 \%)$, but the largest proportion of WTP respondents who felt "bad" (93.83\%) about the local haze situation. The other three cities had about $50 \%$ WTP respondents, with $75 \%$ who felt "bad" about the haze weather. These subjective factors suggest complex motivations for the WTP and WTP amount: those in self-identifying bad haze environments, such as Jinan, but with objective better haze environments (see Table 1), might pay less for haze reductions than those in Zibo and Linyi, with better self-assessed, but worse objective, haze environments. So different cities with different subjective haze ratings might support haze reduction policies for very different reasons, which policy makers should take into consideration when setting and promoting haze reduction policies.

This also applies for differences in respondents' satisfaction with the government's haze reduction credentials. Linyi had the largest proportion of WTP respondents with "confidence" in the government, while Jinan had the largest proportion with a "neutral" belief in the government, which suggests that people in different cities placed a different reliance on the local and provincial government for haze governance, and thus displayed a different WTP. One of the main reasons respondents gave for their unwillingness to pay was their belief that haze governance was mainly the responsibility of governments (39.3\%) and polluters (25.6\%) [1]. Linyi had the lowest proportion (26.55\%) of non-payers who thought haze reduction should be paid by the government, and the highest proportion $(35.40 \%)$ who believed that haze reduction should be paid by polluters. Across the four cities, two contradictory factors were at work: some respondents' distrust of the government to manage haze governance versus the high expectation from other respondents that the government will address the haze problem. Policy makers need to consider the different attitudes to the government when making environmental policy. By placing the responsibility on the government, unwilling to pay respondents believed that they had paid sufficient taxes and that polluters needed to pay to reduce haze. Our data suggest that the government failed to persuade a significant proportion of the residents in certain cities that payment for haze abatement was a public, rather than a government or polluter, problem.

WTP in our survey was significantly lower than the positive WTP for haze governance in previous studies of Chongqing (62\%) and 59.7\% in Jinan [11,12]. Some of the difference might be due to our use of open-ended questions to ask for respondents' WTP amounts instead of the bidding game used in the Chongqing study [12]. Respondents may be more or less sensitive about the price of public goods depending on the question format. Further, Probit models used in previous studies do not easily control for sample selection bias compared to our use of the Heckman selection model. Different WTP amounts in previous studies also reflect different sample characteristics, with our respondents being urban, young, and well educated, with more students and lower paid white-collar workers [11,12].

Income was an important factor in all previous studies of WTP for haze reduction $[10,12,29,30]$. In contrast to Huichen Xian and Hu Meng's study, where awareness of air quality was more important than income in determining WTP, income was the most important determinant of WTP in our model [31]. But, our results show WTP diversity by income across the four cities, so the income factor was mediated by haze awareness and other factors. Our analysis revealed that environmental awareness, including subjective perception and objective behaviors, and satisfaction with the government, had a significant impact on respondents (un)willing to pay. Subjective indicators exerted a negative impact on WTP. Objective indicators and satisfaction with the government exerted a positive impact on respondents' willingness to pay. Our results are consistent with other studies which showed that the public's environmental awareness increases their willing to pay for protecting the environment $[32,33]$.

Like all empirical studies, our WTP findings need careful interpretation. First, the results are based on an urban sample. The results for a sample including rural and industrial workers might be 
different, but are likely to be biased towards lower WTP for haze reduction due to lower education, incomes, and knowledge of environmental issues. Second, clean air is a pure public good, which means that there is a free-rider problem. Our respondents' education level and knowledge of environmental problems may mean that they are aware of the free-rider problem, which decreased their WTP. Also, we should be aware that the WTP based on CVM might not be the same as actual mean WTP [34]. Future studies might employ other CVM techniques, such as discrete-choice models, and alternative approaches, such as payment card methods [35].

\section{Conclusions}

Haze governance is a major aim and challenge for the Chinese government's environmental policies, which address the health and well-being of China's population. Our study investigated the haze attitudes and the WTP for haze governance in four industrial cities in Shandong province. WTP and WTP amount varied by city. The factors driving these differences in WTP and WTP amounts, such as age, income, education, and subjective and objective factors, also differed across the four cities. Finally, the main unwilling to pay reason, the belief that haze governance should be the responsibility of governments and the polluters, also varied across the four cities.

In conclusion, the city-specific differences in WTP may caution against "one size fits all" policies. Broad-based education campaigns, for example, are likely to reach only income, education, and occupational groups already convinced about the pubic good nature of the haze problem. Tailoring policies to specific cities and the characteristics of residents in those cities poses significant challenges to policy making. Targeting subgroups of the city population will require the government to collect more data on the socio-economic factors shaping individual residents characteristics and haze improvement attitudes. This is a daunting task for policy makers and policy implementers. But only by reaching income, age, and education subgroups within a city can environmental policy convince the population to contribute to paying for clean air. China's national level policy pronouncements to bring "blue skies" will depend on how subgroups of residents in individual cities perceive environmental policies. Collecting city-specific subgroup data on environmental attitudes and understanding is the first step to designing targeted interventional strategies to address the haze problem in China.

Author Contributions: Conceptualization, F.Y.; Data curation, F.Y. and L.X.; Formal analysis, F.Y., L.D., S.N., and L.X.; Funding acquisition, J.W.; Investigation, L.D., C.L., and L.X.; Methodology, F.Y.; Project administration, J.W.; Resources, J.W.; Software, L.D.; Supervision, J.W.; Writing-original draft, F.Y.; Writing-review \& editing, S.N. and J.W.

Funding: This project is funded by a Shandong University Innovation Grant. The authors acknowledge funding by the National Natural Science Foundation of China (Grant 71603136, Grant 71702131 and Grant 71373146).

Acknowledgments: We would also like to acknowledge the work of the Horizon Research Consultancy Group. The authors take responsibility for the study.

Conflicts of Interest: The authors declare no conflict of interest.

\section{References}

1. Xue, B.; Mitchell, B.; Geng, Y.; Ren, W.; Müller, K.; Ma, Z.; de Oliveira Jose, A.P.; Tsuyoshi, F.; Tobias, M. A review on China's pollutant emissions reduction assessment. Ecol. Indic. 2014, 38, 272-278. [CrossRef]

2. Geng, Y.; Fu, J.; Sarkis, J.; Xue, B. Towards a national circular economy indicator system in China: An evaluation and critical analysis. J. Clean. Prod. 2012, 23, 216-224. [CrossRef]

3. Xue, B.; Chen, X.P.; Geng, Y.; Yang, M.; Yang, F.X.; Hu, X.F. Energy-based study on eco-economic system of arid and semi-arid region: A case of Gansu Province, China. J. Arid Land 2010, 2, 207-213.

4. Matus, K.; Nam, K.M.; Selin, N.E.; Lamsal, L.N.; Reilly, J.M.; Paltsev, S. Health damages from air pollution in China. Glob. Environ. Chang. 2012, 22, 55-66. [CrossRef]

5. Tao, M.; Chen, L.; Xiong, X.; Zhang, M.; Ma, P.; Tao, J.; Wang, Z. Formation process of the widespread extreme haze pollution over northern China in January 2013: Implications for regional air quality and climate. Atmos. Environ. 2014, 98, 417-425. [CrossRef] 
6. Lee, S.; Oh, D.W. Economic growth and the environment in china: Empirical evidence using prefecture level data. China Econ. Rev. 2015, 36, 73-85. [CrossRef]

7. Huang, D.; Xu, J.; Zhang, S. Valuing the health risks of particulate air pollution in the pearl river delta, China. Environ. Sci. Policy 2012, 15, 38-47. [CrossRef]

8. Xinhuanet. Available online: http://www.xinhuanet.com/english/special/2017-11/03/c_136725942.htm (accessed on 3 November 2017).

9. Reuters. Available online: www.Reuters.com (accessed on 5 October 2017).

10. Wang, Y.; Sun, M.; Yang, X.; Yuan, X. Public awareness and willingness to pay for tackling smog pollution inchina: A case study. J. Clean. Prod. 2016, 112, 1627-1634. [CrossRef]

11. Wang, Y.; Zhang, Y.S. Air quality assessment by contingent valuation in Jinan, China. J. Environ. Manag. 2009, 90, 1022-1029. [CrossRef] [PubMed]

12. Wang, H.; Mullahy, J. Willingness to pay for reducing fatal risk by improving air quality: A contingent valuation study in Chongqing, China. Sci. Total Environ. 2006, 367, 50-57. [CrossRef] [PubMed]

13. Duan, H.X.; Yan-Li, L.; Yan, L. Chinese public's willingness to pay for $\mathrm{CO}_{2}$ emissions reductions: A case study from four provinces/cities. Adv. Clim. Chang. Res. 2014, 5, 100-110. [CrossRef]

14. Xiaoyan, L.I. Empirical analysis of the smog factors in Beijing-Tianjin-Hebei region. Ecol. Econ. 2016. [CrossRef]

15. Wang, J.; Wang, S.; Voorhees, A.S.; Zhao, B.; Jang, C.; Jiang, J.; Fu, J.S.; Ding, D.; Zhu, Y.; Hao, J. Assessment of short-term $\mathrm{PM}_{2.5}$ - Related mortality due to different emission sources in the Yangtze River Delta, China. Atmos. Environ. 2015, 123, 440-448. [CrossRef]

16. Sun, C.; Yuan, X.; Yao, X. Social acceptance towards the air pollution in China: Evidence from public's willingness to pay for smog mitigation. Energy Policy 2016, 92, 313-324. [CrossRef]

17. Zhou, J.; Wang, Y.; Ren, L. Analysis of urban residents' willingness to pay for improving air quality in typical cities in Shandong Province. J. Environ. Health 2010. [CrossRef]

18. National Bureau of Statistics of China. China Statistical Yearbook 2015; China Statistics Press: Beijing, China, 2015.

19. Mitchell, R.C. Using survey to value public goods. Resour. Futur. 1989, 29, 900-902.

20. Richard, C.B.; Patricia, A.C.; Daniel, J.M. Contingent valuation. In The Handbook of Environmental Economics; Bromley, D.W., Ed.; Blackwell Publishers Ltd.: Hoboken, NJ, USA, 1995; pp. 62-95.

21. Sattout, E.J.; Talhouk, S.N.; Caligari, P.D.S. Economic value of cedar relics in Lebanon: An application of contingent valuation method for conservation. Ecol. Econ. 2007, 61, 315-322. [CrossRef]

22. Birdir, S.; Özlem, Ü.; Birdir, K.; Williams, A.T. Willingness to pay as an economic instrument for coastal tourism management: Cases from Mersin, Turkey. Tour. Manag. 2013, 36, 279-283. [CrossRef]

23. Whittington, D. Improving the performance of contingent valuation studies in developing countries. Environ. Resour. Econ. 2002, 22, 323-367. [CrossRef]

24. Choongki, L.; Han, S.Y. Estimating the use and preservation values of national parks' tourism resources using a contingent valuation method. Tour. Manag. 2002, 23, 531-540.

25. Heckman, J.J. Sample selection bias as a specification error. Econometrica 1979, 47, 153-161. [CrossRef]

26. Greene, W.H. Econometric Analysis, 6th ed.; Prentice Hall: New Jersey, NJ, USA, 2008.

27. Zhang, W. Shandong: A good example of China in transition. Bus. Week 2010, 8, 43-44. (In Chinese)

28. Xu, X.; Gao, J.; Dockery, D.W.; Chen, Y. Air pollution and daily mortality in residential areas of Beijing, China. Arch. Environ. Health 1994, 49, 216. [CrossRef] [PubMed]

29. Wang, G.; Song, Y.; Chen, J.; Yu, J. Valuation of haze management and prevention using the contingent valuation method with the sure independence screening algorithm. Sustainability 2016, 8, 310. [CrossRef]

30. Sun, C.; Yuan, X.; Xu, M. The public perceptions and willingness to pay: From the perspective of the smog crisis in China. J. Clean. Prod. 2014, 112, 1635-1644. [CrossRef]

31. Xian, H.; Hu, M. The study of the residents'willingness to pay for improving air quality in Qingdao. Urban Dev. Stud. 2013, 20, 95-100. (In Chinese)

32. Cuddington, J.T.; Johnson, F.R.; Knetsch, J.L. Valuing amenity resources in the presence of substitutes. Land Econ. 1981, 57, 526-535. [CrossRef]

33. Muhammad, M.; AbulQuasem, A.-A.; RuliaAkhtar, F.K.; RafiaAfroz, M.R. Valuing climate protection by offsetting carbon emissions: Rethinking environmental governance. J. Clean. Prod. 2015, 89, 41-49. 
34. Carlson, J.L. Hypothetical surveys versus real commitments: Further evidence. Appl. Econ. Lett. 2000, 7, 447-450. [CrossRef]

35. Bosch, J.L.; Hammitt, J.K.; Weinstein, M.C.; Hunink, M.G.M. Estimating general-population utilities using one binary-gamble question per respondent. Int. J. Soc. Med. Decis. Mak. 1998, 18, 381. [CrossRef] [PubMed] 